\title{
RESPONSE OF SOYBEAN GENOTYPES TO THE EXPRESSION OF GREEN SEED UNDER TEMPERATURE AND WATER STRESSES ${ }^{1}$
}

\author{
GILDA PIZZOLANTE DE PÁDUA², MARIA LAENE MOREIRA DE CARVALHO³, \\ JOSÉ DE BARROS FRANÇA-NETO4, MÁRIO CÉSAR GUERREIRO ${ }^{5}$, RENATO MENDES GUIMARÃES ${ }^{6}$
}

\begin{abstract}
Soybeans grown under water stress associated with high temperatures during seed maturation and pre-harvest may produce green seed (GS) with expressive reduction in seed quality. The objectives of this study were to evaluate the response of different soybean cultivars grown under these stressful conditions regarding their susceptibility to GS production and to determine the chlorophyll retention levels and the chlorophyllase activity in the seeds. Seeds of four soybean cultivars [BRS 133, CD 206, MG/BR 46 (Conquista) and BRSMG 251 (Robusta)] were grown under greenhouse conditions until $\mathrm{R}_{5.5}$. At $\mathrm{R}_{6}$, the plants were transferred to phytotrons under temperature stress (from $28^{\circ} \mathrm{C}$ to $36^{\circ} \mathrm{C}$ ) and with water stresses of $10 \%$ gravimetric moisture, no water and normal supply. Seeds were harvested at $\mathrm{R}_{9}$ when the percentage of GS and weight of 100 seeds were determined. The contents of $a, b$ and total chlorophylls and the chlorophyllase activity were also determined. The expression of GS production under these conditions varied among cultivars: Conquista and Robusta were considered more susceptible to the production of GS compared to 'BRS 133 ' and 'CD 206'. These cultivars produced lower GS levels, lower chlorophyll retention and higher chlorophyllase activity compared to Robusta and Conquista. Soybean plants submitted to water and temperature stresses produced high levels of GS, which were small, light and had high chlorophyll contents and low chlorophyllase activity. The contents of $a, b$ and total chlorophylls in GS were inversely proportional to the chlorophyllase activity.
\end{abstract}

Index terms: Glycine max, chlorophyll, chlorophyllase, seed quality

\section{REAÇÃO DE GENÓTIPOS DE SOJA QUANTO À EXPRESSÃO DE SEMENTES VERDES EM CONDIÇÕES DE ESTRESSES TÉRMICO E HÍDRICO}

RESUMO - Plantas de soja submetidas a estresses ambientais, como deficiência hídrica, principalmente se associados com elevadas temperaturas, durante a fase final de maturação e précolheita das sementes, podem ocasionar a produção de semente verde, com redução expressiva na sua qualidade. Para verificar o comportamento de genótipos de soja considerados tolerantes e suscetíveis à produção de semente verde sob condições de estresse e avaliar essa ocorrência e seus efeitos sobre a retenção de clorofila e a atividade da enzima clorofilase em sementes de soja, foram avaliados

\footnotetext{
${ }^{1}$ Submetido em 18/08/2009. Aceito para publicação em 17/09/2009. Parte da Tese de Doutorado do primeiro autor apresentada a UFLA.
}

${ }^{2}$ Eng. Agr., Dra. Pesquisadora da Embrapa/EPAMIG, Caixa Postal 351, CEP 38.001-970. Uberaba - MG. gpadua@epamiguberaba.com.br

${ }^{3}$ Eng. Agr., Dra. Professora do Departamento de Agricultura, UFLA, Caixa Postal 3037, CEP 37.200-000. Lavras - MG. mlaenemc@ufla.br
${ }^{4}$ Eng. Agr., Dr. Pesquisador da Embrapa Soja, Caixa Postal 231, CEP 38.001-970. Londrina - PR.jbfranca@cnpso.embrapa.br

${ }^{5}$ Eng. Agr., Dr. Professor do Departamento de Química, UFLA, Caixa Postal 3037, CEP 37.200-000. Lavras - MG. guerrero@ufla.br

${ }^{6}$ Eng. Agr., Dr. Professor do Departamento de Agricultura, UFLA, Caixa Postal 3037, CEP 37.200-000. Lavras - MG. renatomg@ufla.br. 
quatro genótipos de soja. Sementes das cultivares BRS 133, CD 206, MG/BR 46 (Conquista) e BRS 251 (Robusta) foram produzidas em casa de vegetação até o estádio de desenvolvimento $\mathrm{R}_{5.5}$. A partir do estádio $\mathrm{R}_{6}$, as plantas foram transferidas para fitotrons, para a indução de estresse térmico, de $28^{\circ} \mathrm{C}$ a $36^{\circ} \mathrm{C}$ associado a estresse hídrico. A quantidade de água nos vasos foi controlada nos seguintes níveis: testemunha, $10 \%$ de umidade gravimétrica e corte total de irrigação. As sementes foram colhidas em $\mathrm{R}_{9}$, avaliando-se o porcentual de sementes verdes e o peso de 100 sementes. Foram também determinados os teores de clorofila $a, b$ e total e a atividade da enzima clorofilase. Existe variação de resposta à retenção de clorofilas em sementes de cultivares de soja produzidas em condições de estresse hídrico e térmico. As cultivares Conquista e Robusta são suscetíveis e a 'BRS 133' é menos suscetível às condições de estresse que causam o esverdeamento. As cultivares BRS 133 e CD 206 apresentam menor índice de semente verde, menor retenção de clorofilas $a, b$ e total e maior atividade da enzima clorofilase, em relação às cultivares Conquista e Robusta, sob condição de estresse. Plantas de soja submetidas às condições de estresse hídrico e térmico produzem altos índices de sementes verdes, menores e mais leves, com elevado teor de clorofilas e baixa atividade de clorofilase. O conteúdo de clorofilas $a, b$ e total, em sementes verdes de soja é inversamente proporcional à atividade da enzima clorofilase.

Termos para indexação: Glycine max, clorofila, clorofilase, qualidade fisiológica

\section{INTRODUCTION}

Environmental stresses, especially those caused by high temperatures during soybean maturation, can cause severe losses to seed production and quality. There is a very fast reserve translocation and lower photosynthesis rates in this phase that prevent complete chlorophyll degradation that causes the formation of green and low quality seed (Marcos Filho, 2005).

The chlorophyll degradation process can be affected by external factors, such as environmental stress, or by internal factors, such as increased membrane permeability and change in $\mathrm{pH}$ (Heaton and Marangoni, 1996). Furthermore, the chlorophyll levels present in the seed seem to be affected equally by the genotype and climatic conditions, especially temperature, because under the same production conditions, cultivars have responded differently regarding chlorophyll retention at the end of the maturation phase.

For most species, the quantity of chlorophyll in the seed decreases during the maturation process through the actions of the chlorophyllase and magnesium chelatase enzymes, that degrade the chlorophyll resulting in the loss of the green coloring of the seed (Heaton and Marangoni, 1996). Under favorable conditions, the plants mature and the enzymes degrade the chlorophyll, resulting in the normal coloring of soybean seed. This activity is affected in the summer if the climate is extremely hot and dry during the last seed maturation stages. It is believed that with the premature death of the plants and the consequent forced maturation of the seeds, the activity of the chlorophyllase enzyme ceases before all the chlorophyll is degraded (Bohner, 2002).

There are few studies on the processes and mechanisms that account for the physiological degradation of the chlorophyll as a post-harvest biochemical process or senesance and the causes and effects of chlorophyll retention in soybean seed. Apparently it is an enzymatic process, shown by an increase in the chlorophyllids, although it is coupled to a non-enzymatic chemical mechanism that results in an increase of pheophytins and other phytilated derivatives (Heaton and Marangoni, 1996; Mangos and Berger, 1997; Suzuki et al., 1999).

Bohner (2002) reported two types of green soybean in the USA. The first category was characterized by the green coloring of the external part of the seed, while the inside remained yellow. In the second category, the green coloring was found throughout the seed that was classified as damaged seed and discounted from the American producers, because chlorophyll is carried to the oil during processing and has a direct effect on its quality. According to França-Neto et al. (2005), soybean seeds with intense green or even greenish coloring generally present high levels of deterioration that can result in reduced germination, vigor and viability in soybean seed lots.

Thus the objective of this research was to verify the performance of soybean genotypes for tolerance or susceptibility to green seed production under stress conditions 
and to assess this occurrence regarding chlorophyll retention and chlorophyllase enzyme activity in soybean seed.

\section{MATERIALS AND METHODS}

\section{Plant materials}

The short cycle cultivars BRS 133 and CD 206 and late cycle MG/BR 46 (Conquista) and BRS 251 (Robusta) cultivars were produced in a greenhouse at Embrapa Soybean in Londrina, PR, Brazil. The seed quality analyses were carried out in the Seed Analysis Laboratory at the Federal University of Lavras, Lavras, Brazil.

\section{Temperature and water stress}

Temperature and water stress were induced at the $\mathrm{R}_{6}$ stage of soybean maturation, characterized by pods with $100 \%$ full seed and green leaves (Ritchie et al., 1994). Phytotrons were used to induce temperature stress with high temperatures $\left(28^{\circ} \mathrm{C}\right.$ from 5 p.m. to 8 a.m.; $32^{\circ} \mathrm{C}$ from 8 a.m. to 10 a.m.; $36^{\circ} \mathrm{C}$ from 10 a.m. to 2 p.m. and $32^{\circ} \mathrm{C}$ from 2 p.m. to 5 p.m.). A $12.5 \mathrm{~h}$ photoperiod was used, from 7 a.m. to 7:30 p.m.

Water stress was carried out under three water availability conditions in the soil. The quantity of water in the pots was controlled at the following levels: control (about 1.0L water supplied daily to the plants in each pot with $7.0 \mathrm{~kg}$ of soil); $10 \%$ gravimetric moisture (GM) and no water (total cut in irrigation). The gravimetric moisture was calculated by the ratio between the water mass present in a soil sample and the dry mass of the same sample (Embrapa, 1997). Each pot was weighed daily and the soil water contents adjusted. The quantity of water to be added per pot to reach the level of $10 \%$ GM was calculated based on the average dry weight of the soil. This value was maintained by daily weighing of the pots, excluding the average weight of the plants and the weight of the pot.

\section{Green seed percentage and weight of 100 seeds}

The seeds were collected at $\mathrm{R}_{9}$, point of harvest maturation, and 12 plants were assessed (two plants per pot, in a total of six pots) per treatment. The green seed percentage was calculated by the total number of seeds produced in the upper, mid and lower thirds of each plant. The weight of 100 seeds was obtained by using 100 seeds produced in the three thirds of each plant and the average of the data was expressed in grams.

\section{Seed preparation}

After these assessments, the seeds from the upper, mid and lower thirds of the plants were grouped to determine the $a, b$ and total chlorophyll and the chlorophyllase enzyme activity. Thirty-six seeds from each sub-sample were ground using liquid nitrogen and an aliquot of PVP (Polyvinyl Pyrrolidone), weighed, packed in black plastic recipients and stored in a deep freezer at $-86^{\circ} \mathrm{C}$ until manipulation.

\section{Chlorophyll contents}

The method by Arnon (1949) was used, adapted as reported next. The stored samples were used in the chlorophyll extraction, $2.5 \mathrm{~g}$ ground seed were weighed and squashed with a small quantity of $80 \%$ acetone in a dark room, using green light. The extract was filtered through fiberglass and placed in an amber flask. The macerate was washed until it completed $15 \mathrm{~mL}$ extract, kept in an ice bath until the absorbency was read in a spectrophotometer, at 645 and $663 \mathrm{~nm}$ wave length. The $a, b$ and total chlorophyll results were expressed in $\mathrm{mg} \cdot \mathrm{g}^{-1}$.

\section{Chlorophyllase enzyme activity}

Ketonic powder: $1 \mathrm{~g}$ ground seed, from the stored samples, was homogenized in a porcelain pestle with $2 \mathrm{~mL}$ acetone p.a., at $4^{\circ} \mathrm{C}$. The supernatant, containing acetate and pigments, was filtered through Qualy filter paper $(80 \mathrm{~g} /$ $\mathrm{m}^{2}$ gramature) under vacuum and the solid material was retained in the pestle and washed twice with two $\mathrm{mL}$ acetone to remove excess pigments. The ketonic powder retained in the pestle was dried at room temperature, weighed and stored in a refrigerator (Sabater and Rodriguez, 1978).

Substrate for chlorophyllase: soybean leaves from each cultivar were collected from the third trifoliate, washed in distilled water and dried on paper towel. The central nervure was removed with a scalpel, and $2 \mathrm{~g}$ fresh leaf weight per cultivar were squashed with a small quantity of acetone at $4^{\circ} \mathrm{C}$ and filtered through Qualy filter paper under vacuum. The macerate was washed until $15 \mathrm{~mL}$ substrate and was then stored at $4^{\circ} \mathrm{C}$ for three days. The samples were homogenized inside a chamber with an exhaust system, with the laboratory lights turned out, closed curtains and the glassware containing the substrates was wrapped in aluminum foil. After this period, the carotenoids precipitated during storage were removed by filtrating through Qualy filter paper. The filtrates obtained were used as substrate for the chlorophyllase enzyme.

Enzymatic activity: chlorophyllase activity was expressed in terms of enzymatic unit (UE)/g ketonic powder $(\mathrm{KP})$, by the difference between the calculations of the 
enzymatic activity in the time of 24 hours and the enzymatic activity in the time zero hours, based on the break of the substrate to chlorophyllideo in 24 hours. Activity at time zero was established by weighing $5 \mathrm{mg}$ ketonic powder from each sample mixed with $0.8 \mathrm{~mL}$ chlorophyll solution, $0.4 \mathrm{~mL}$ sodium citrate solution (final concentrations acetone $=60 \%$; citrate $=0.04 \mathrm{M}$ ) and $1 \mathrm{~mL} \mathrm{NaCl} 2 \%$ (weight/volume) to block the enzyme activity. The final volume was taken to $25 \mathrm{~mL}$ with $80 \%$ acetone, and read in a spectrophotometer with visible UV (UV 1601 PC - Shimadzu), on the scale of $400 \mathrm{~nm}$ to $700 \mathrm{~nm}$. The enzymatic activity was calculated by the difference between the readings of the highest values (spectrum peak) of the treatments and the control reading. For the enzymatic activity at time 24 hours, $5 \mathrm{mg}$ ketonic powder of each sample were mixed with $0.8 \mathrm{~mL}$ chlorophyll solution, $0.4 \mathrm{~mL}$ sodium citrate solution (final concentrations acetone $=$ $60 \%$; citrate $=0.04 \mathrm{M}$ ) and incubated at $30^{\circ} \mathrm{C}$ in the dark for 24 hours. After this time, the supernatant was removed with a Pasteur pipette and the solid material retained in the test tube was washed with a further $1 \mathrm{~mL}$ acetone to completely remove the pigments. An aliquot of $1 \mathrm{~mL} 2 \% \mathrm{NaCl}$ (weight/ volume) was added to block the enzyme activity and the volume was completed to $25 \mathrm{~mL}$ with $80 \%$ acetone. Readings were made in a spectrophotometer with visible UV (UV $1601 \mathrm{PC}-$ Shimadzu), on the scale de $400 \mathrm{~nm}$ to $700 \mathrm{~nm}$. The enzymatic activity was calculated from the difference between the readings of the treatments and the control.

\section{Statistical analysis}

A randomized complete block experimental design was used with six replications in a $4 \times 3$ factorial design (four cultivars, three water levels), for the variables green seed percentage and weight of 100 seeds, and only one exploratory data analysis was made by constructing a Box plot. For the other variables, a randomized complete experimental design was used with three replications, in a $4 \times 3$ factorial design (four cultivars, three water levels). The data were interpreted statistically by analysis of variance and the means were compared by the Scott-Knott test at 5\% probability. The statistical softwares $\mathrm{R}^{\circledR} \mathrm{v} 2.1 .1$ (R, 2005) and SISVAR ${ }^{\circledR} \mathrm{v} 4.3$ (Ferreira, 2000) were used for all the statistical analyses carried out in this study.

\section{RESULTS AND DISCUSSION}

The results obtained, in function of the different cultivars, Figure 1(a), showed lower green seed indices in the BRS 133 and CD 206 cultivars. Data are presented in graphs depicted by Box plots. They are represented by the lower limit of the box, where there are $50 \%$ of the data, and by the upper limit, with $75 \%$ of the data. The mean is represented by the dot inside the Box plots and the mode by the internal line. The line above and below the Box plots represents the total range of the data and the dots above this line are the outliers. Greatest susceptibility was observed in the MG/BR 46 Conquista cultivar for this characteristic, with $31.1 \%$ occurrence and high indices of green seed were detected in the seeds from the BRS 251 (Robusta) cultivar, with an average of $60 \%$. The high green seed indices in the BRS 251 Robusta cultivar showed the susceptibility of the genotype, but some aspects should be considered, such as the difficulty in standardizing the development stages for the different cultivars and the smaller seed size of Robusta, that may have contributed to a premature classification of the $R_{6}$ stage and consequently greater stress effect. Several authors have reported difficulties in establishing precise identifications among the seed development stages and the irregularity of maturation among plants (Crookston and Hill, 1978; Blackman et al., 1992; Marcos Filho, 2005).

Adverse climatic conditions, such as intense drought during the histodifferentiation and maturation phases in the soybean crop, result in forced seed maturation that causes low yields and the occurrence of green seed that sharply reduces seed quality, in addition to severely reducing the field productivity (França-Neto et al., 2005). This problem has been reported in the Cerrado region in Brazil, China (Theanjumpol, 2002), in several regions close to Ontario, in Canada and in the region of Kansas in the USA (Bohner, 2002).

A study by Costa et al. (2001) in the states of Goias and Minas Gerais, Brazil, reported that green seed found in soybean seed lots may be associated to adverse climatic conditions during seed filling and maturation or to the genetic constitution of the cultivars themselves. In this sense, FrançaNeto et al. (2005) in a study carried out in the state of Mato Grosso, Brazil, reported that some cultivars presented greater susceptibility to green seed production when submitted to the same stress level.

The values detected for the green seed percentage in function of water stress are shown in Figure 1(b). No green seed occurred in the treatment with adequate water supply (control). On the other hand, in plants submitted to stresses of $10 \% \mathrm{GM}$ and no water, $33.5 \%$ and $58.6 \%$ green seed were observed on average, respectively. In this research, soybean plants submitted to water and temperature stress conditions produced high green seed indices and smaller and lighter seed. Tekrony et al. (1980) reported that adverse 
climatic conditions are problematic for seed quantity in many crops and generally high temperatures and humidity

(a)

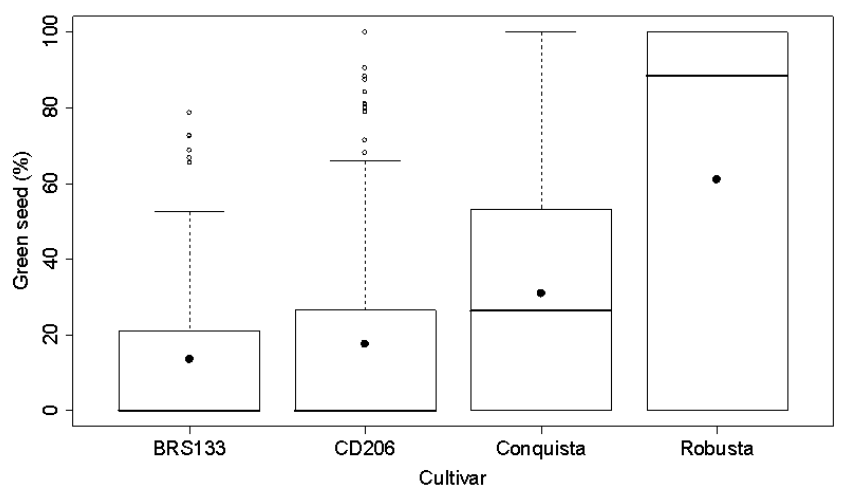

are the environmental factors that most contribute to seed deterioration caused by weathering.

(b)

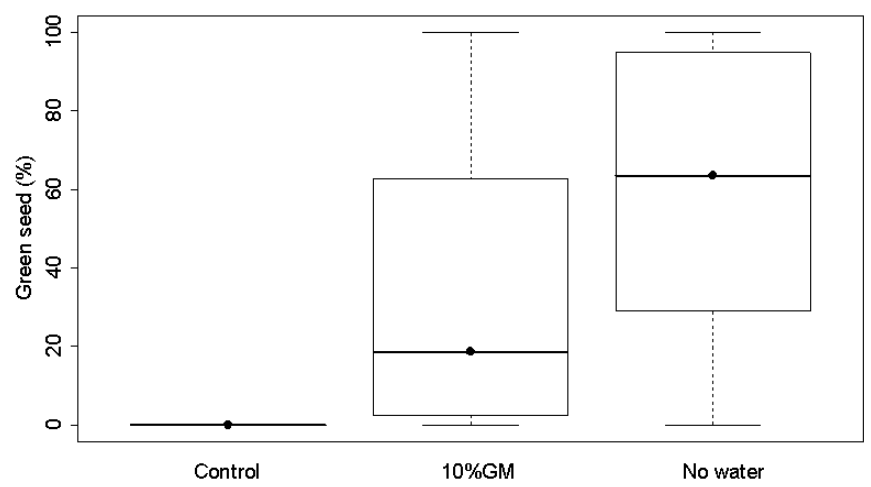

FIGURE 1. Occurrence of green seed (\%) in soybean plants, as a function of water-deficit (control, 10\% GM, no water) and heat stresses $\left(28^{\circ} \mathrm{C}\right.$ to $\left.36^{\circ} \mathrm{C}\right)$, according to the four cultivars (a) and to the conditions of soil water availability (b). Graphics depicted by Box-plots, where the mean is represented by the dot inside the Box plots and the mode by the internal line. The line above and below the Box plots represents the total range of the data and the dots above this line are the outliers.

Data in Figure 2 illustrate that when the results for seed weight were compared among the cultivars submitted to high temperatures and water stress, they performed differently to each other and high seed weight values were observed in the seeds from the CD 206 and MG/BR 46 Conquista cultivars, followed by BRS 113 and BRS 251 Robusta, whose average result was 12.4g. Evidence from research with different species has led to the conclusion that the seed development rate

(a)

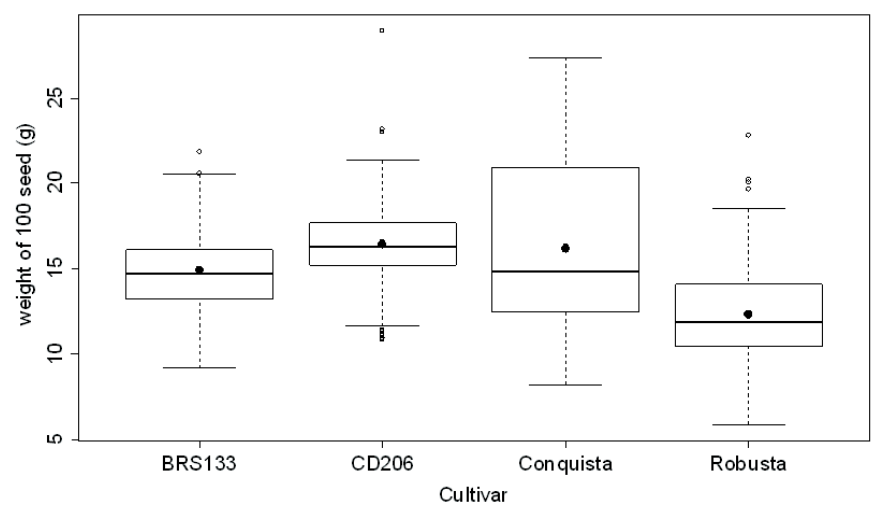

is controlled genetically and varies according to the species and cultivar. According to Egli (1998) the final seed weight depends on the rate and period of dry matter accumulation and the final number of seeds and the rate exert less influence on the final production than the dry matter accumulation period. Changes in the assimilate supply are probably explained by many of the environmental effects, where genetic differences are probably regulated by the seed.

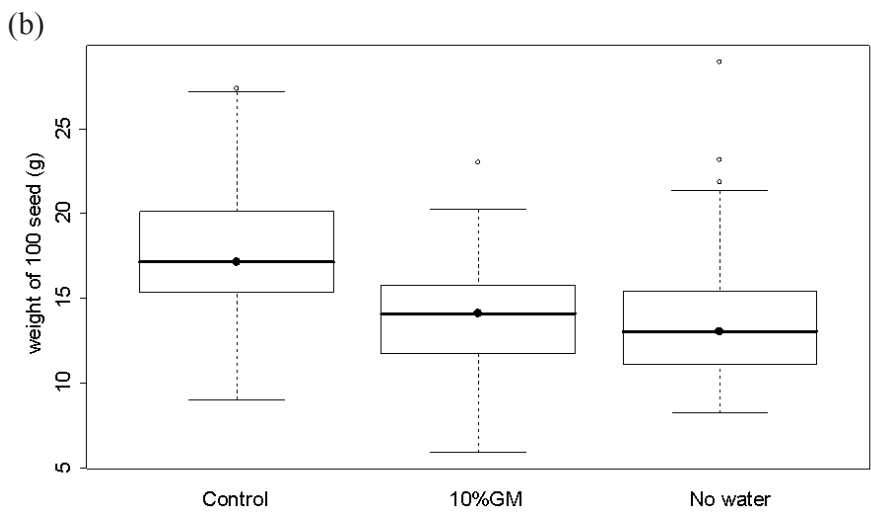

FIGURE 2. Weight of 100 seeds (g) obtained from soybean plants, as a function of water-deficit (control, $10 \%$ GM, no water) and heat stresses $\left(28^{\circ} \mathrm{C}\right.$ to $\left.36^{\circ} \mathrm{C}\right)$, according to the four cultivars (a) and the conditions of soil water availability (b). Graphics depicted by Box-plots, where the mean is represented by the dot inside the Box plots and the mode by the internal line. The line above and below the Box plots represents the total range of the data and the dots above this line are the outliers. 
The results of the weight of 100 seeds after high temperature and water stress induction are shown in Figure 2(b). The plants submitted to $10 \%$ GM water shortage and no water gave rise to smaller seed, with average weight of $13.8 \mathrm{~g}$ and $13.5 \mathrm{~g}$, respectively, compared to those of the control, which had an average value of $17.6 \mathrm{~g}$.

The results presented were in line with reports in the literature, that water shortages accelerate the reserve accumulation process, giving rise to less dense seed with reduced performance (Marcos Filho, 2005); and when they occur during the dry matter accumulation period, they sharply reduce yield because of the formation of smaller and lighter and, depending on the cultivar, wrinkled and deformed seeds (França-Neto and Krzyzanowski, 1990). Furthermore, Dornbos and McDonald (1986) emphasized that the critical period of reserve accumulation by soybean seed occurs between the $R_{5}$ and $R_{7}$ stages. Therefore, it is pointed out that at $R_{6}$, the stage at which stress was imposed, the plant was still very sensitive to periods of water shortage.

Water shortage during seed filling accelerates leaf senesance and shortens the seed filling period in soybean. Under water shortage, these seeds may not complete the same developmental sequence as non-stressed plants and the seed composition may be affected in the mature seed (Egli, 1998).

In the statistical analyses of the chlorophyll contents, the factors cultivar and water availability conditions presented highly significant differences $(\mathrm{P}<0.01)$ in all the analyses performed. The interaction between the two factors was highly significant $(\mathrm{P}<0.01)$ for $a$ chlorophyll content but not significant for $b$ and total chlorophyll contents and chlorophyllase activity.

The results of the $a, b$ and total chlorophyll contents are shown in Figures 3 to 7 . There were no statistical differences for chlorophyll content among the cultivars assessed in the control and 10\% GM treatment (Figure 3). In the control treatment, where the seeds were not submitted to stress, there was normal chlorophyll degradation. However, in the $10 \%$ GM condition, $a$ chlorophyll contents were greater compared to the control for all the cultivars. Under more stressful conditions, without water, the smallest $a$ chlorophyll content was observed in the BRS 133 cultivar that differed statistically from the others followed by the CD 206 and $\mathrm{MG} / \mathrm{BR} 46$ Conquista cultivars, that were the same, and the greatest chlorophyll retention was detected in the BRS 251 Robusta cultivar.

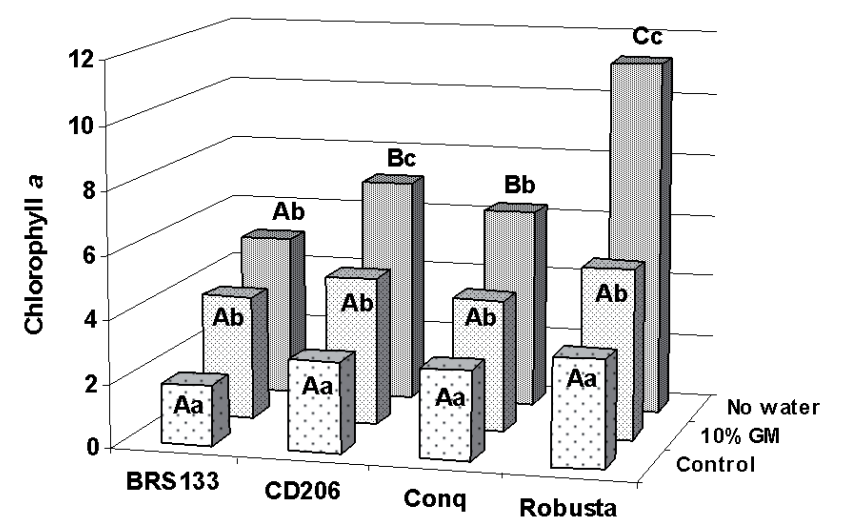

FIGURE 3. Chlorophyll a contents $\left(\mathrm{mg}^{-\mathrm{g}^{-1}}\right)$ in soybean seeds of the cultivars BRS 133, CD 206, Conquista and Robusta, produced under water stress (control, $10 \%$ GM and no water) and heat stress $\left(28^{\circ} \mathrm{C}\right.$ to $\left.36^{\circ} \mathrm{C}\right)$. Cultivar comparisons are made with capital letters and water stress with small letters.

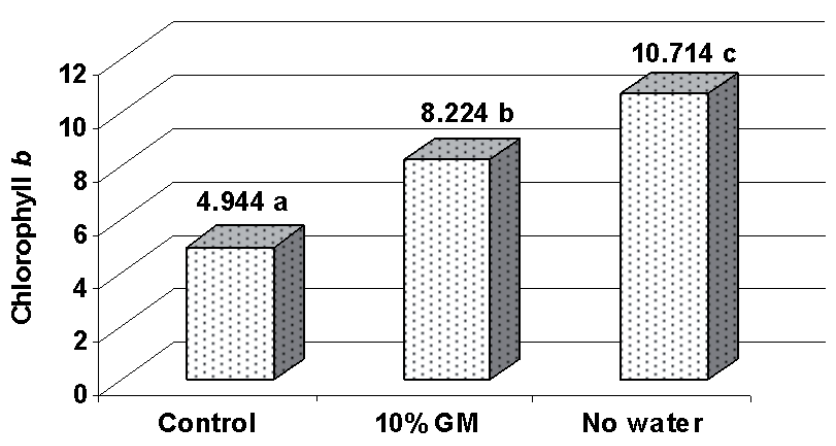

FIGURE 4. Chlorophyll b contents (mg.g $\left.{ }^{-1}\right)$ in soybean seeds produced under water stress (control, $10 \%$ GM and no water) and temperature stress $\left(28^{\circ} \mathrm{C}\right.$ to $\left.36^{\circ} \mathrm{C}\right)$.

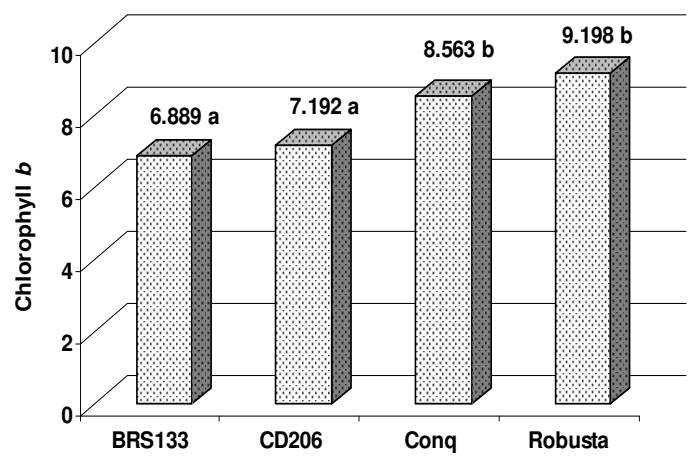

FIGURE 5. Chlorophyll b contents (mg.g $\left.{ }^{-1}\right)$ in soybean seeds of the cultivars BRS 133, CD 206, Conquista and Robusta produced under water stress (control, 10\% GM and no water) and heat stress $\left(28^{\circ} \mathrm{C}\right.$ to $\left.36^{\circ} \mathrm{C}\right)$. 


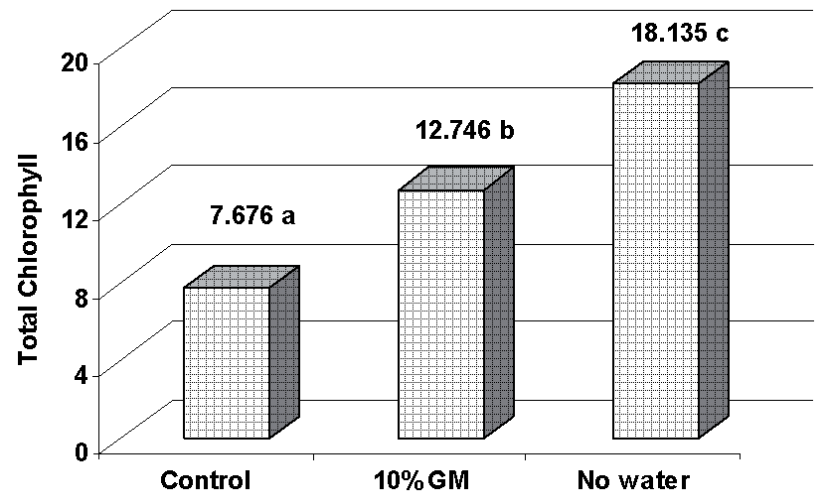

FIGURE 6. Total chlorophyll contents $\left(\mathrm{mg}^{-1} \mathrm{~g}^{-1}\right)$ in soybean seeds produced under water stress (control, $10 \%$ GM and no water) and heat stress $\left(28^{\circ} \mathrm{C}\right.$ to $\left.36^{\circ} \mathrm{C}\right)$.

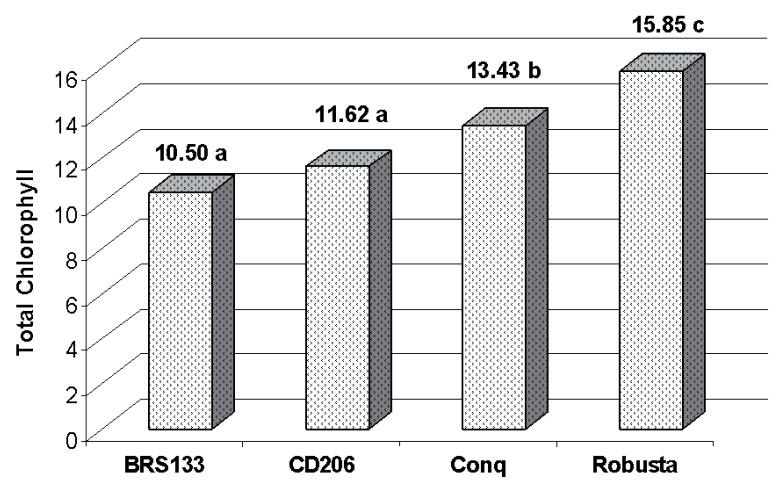

FIGURE 7. Total chlorophyll contents $\left(\mathrm{mg.g}^{-1}\right)$ in soybean seeds of the cultivars BRS 133, CD 206, Conquista and Robusta produced under water stress (control, 10\% GM and no water) and heat stress $\left(28^{\circ} \mathrm{C}\right.$ to $\left.36^{\circ} \mathrm{C}\right)$.

Regarding the results observed, for the chlorophyll levels present in the seed, this research confirmed the reports by several authors that chlorophyll degradation was affected equally by the genotype and climatic conditions, as McGregor (1991) reported when working with rape seed and Costa et al. (2001) and França-Neto et al. (2005) reported for soybean. Other studies report the influence of the genotype (Stangarlin, 1999 and Stangarlin et al. 2000 , working with common bean) and dependency on environmental conditions and drying temperature (Heaton and Marangoni, 1996; Takamiya et al., 2000; Sinnecker, 2002) on the expression of the green seed characteristic.

Chlorophyll degradation starts at senescence due to endogenous factors and may also be influenced by external factors, such as water stress. In the soybean seed submitted to conditions of $10 \% \mathrm{GM}$ and no water there were high $b$ chlorophyll contents compared with those produced with adequate water supply (Figure 4). These results were in line with reports by Takamiya et al. (2000) that external factors, such as water stress and temperature changes, interfered in the normal process, leading to accelerated or delayed chlorophyll degradation.

Figure 5 shows that the seeds from the BRS 113 and CD 206 cultivars presented low $b$ chlorophyll contents after high temperature and water stress induction. Confirming the results detected in the $a$ chlorophyll contents (Figure 3 ) it was also observed for $b$ chlorophyll (Figure 5) that the MG/BR 46 Conquista and BRS 251 Robusta cultivars were more susceptible to green seed production (Figure 1a). According to Sinnecker (2002) soybean seed harvested at premature maturation stage $\left(\mathrm{R}_{6}\right)$ contains high chlorophyll contents.

The total chlorophyll content (Figures 6 and 7) expresses, in general terms, the results observed for the $a$ and $b$ chlorophylls. High total chlorophyll contents were detected in soybean seed submitted to $10 \% \mathrm{GM}$ and no water, which differed statistically when compared with those produced with adequate water supply (Figure 6).

The results of the total chlorophyll content among the cultivars assessed are illustrated in Figure 7. The seeds from the BRS 113 and CD 206 cultivars presented the lowest total chlorophyll contents, not differing from each other, followed by the MG/BR 46 Conquista cultivar, that presented intermediate values, and by the BRS 251 Robusta cultivar, which presented the greatest chlorophyll retention.

The activity and expression of the chlorophyllase enzyme for the water stress factor are presented in Figure 8 and for the facto cultivars in Figure 9. As expected, the greatest enzymatic activity was observed in the control (Figure 8), because in this treatment, smaller pigment contents were detected, both for $a$ and $b$ chlorophylls. There was no statistical difference for the chlorophyllase enzyme under $10 \%$ GM and no water and both presented less activity. Bohner (2002) pointed out that under normal circumstances, the plant matures and the chlorophyllase enzyme degrades the chlorophyll present in the soybean seed. This activity is affected during the last seed maturation stages and under extremely hot and dry conditions. It is believed that with the premature death of the plants and the consequent forced seed maturation, the chlorophyllase activity stops before all the chlorophyll is degraded. 


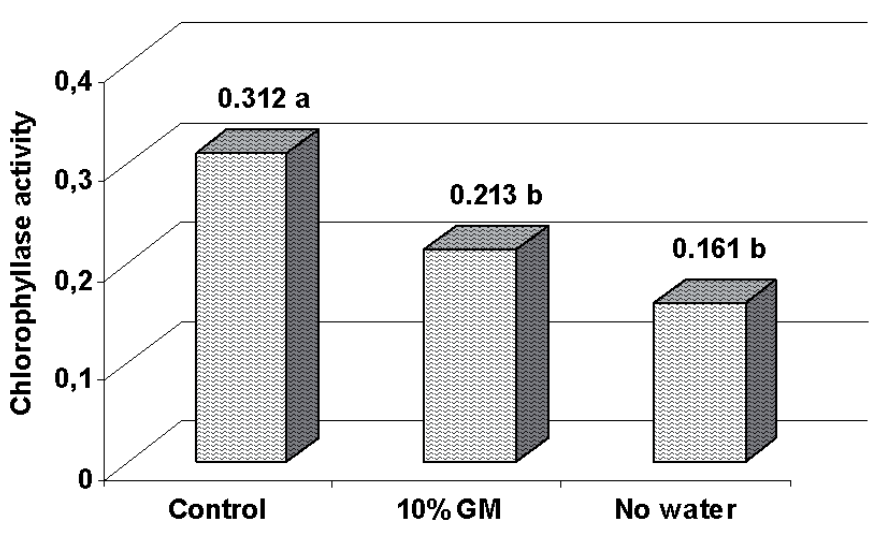

FIGURE 8. Chlorophyllase activity (UE.g ${ }^{-1}$ ketonic powder) in soybean seeds produced under water stress (control, $10 \%$ GM, no water) and heat stress $\left(28^{\circ} \mathrm{C}\right.$ to $\left.36^{\circ} \mathrm{C}\right)$.

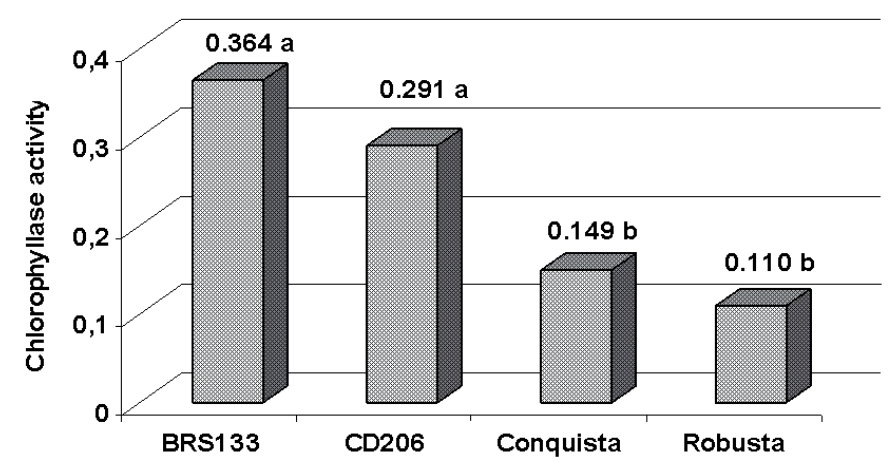

FIGURE 9. Chlorophyllase activity (UE.g ${ }^{-1}$ ketonic powder) in soybean seeds of the cultivars BRS 133, CD 206, Conquista and Robusta produced under water stress (control, $10 \%$ GM, no water) and heat stress $\left(28^{\circ} \mathrm{C}\right.$ to $\left.36^{\circ} \mathrm{C}\right)$.

The results obtained in this research are comparable to those reported by Stangarlin (1999) and by Stangarlin et al. (2000), who verified, based on the chlorophyll content and the activity of the chlorophyllase and rubisco enzymes, interference in the photosynthetic system of common bean cultivars infected by pathogens. These authors observed greater enzymatic activity in the regions infected with the pathogens, that is, regions that presented low $a$ chlorophyll contents per unit of remaining green area. They observed an inverse relationship between the chlorophyll concentration and chlorophyllase enzyme activity, indicating that reduction in the content of these green pigments probably occurs because of enzymatic lyse and not because their synthesis is suppressed.

The enzymatic activity among soybean cultivars after high temperature and water shortage induction is illustrated in Figure 9. The highest activity was observed in the BRS 113 cultivar and the lowest in the BRS 251 Robusta cultivar, which presented the smallest and largest pigment contents, respectively. However, a different performance was observed between the CD 206 and MG/ BR 46 Conquista cultivars, which presented the highest and lowest chlorophyllase activity, and the smallest and greatest $b$ chlorophyll (Figure 5) and total chlorophyll contents (Figure 7). On the other hand, this performance was not detected for $a$ chlorophyll (Figure 3) because there were no statistical differences between them. This fact may be attributed to the possibility of other enzymes, in addition to chlorophyllase, acting on chlorophyll degradation, as reported in the related literature.

A different performance was shown among the soybean cultivars regarding the enzymatic activity of chlorophyllase. This fact can probably be explained by the action of other enzymes, such as magnesium-kelatase and oxygenases that may act directly on the chlorophyll or its derivatives (Heaton and Marangoni, 1996; Takamyia et al., 2000). These authors also stated that the removal of the phytol group sharply increased the chlorophyll molecule polarity that consequently decreased its stability in the thylakoid membrane.

Research by Tewari and Tripathy (1998) in melon and wheat detected that temperature stress induced decrease in the chlorophyll biosynthetic reaction caused by inactivation of the enzymes involved in the process, mainly magnesiumkelatase.

The results reported by Sinnecker (2002) for soybean reinforced this hypothesis and also that chlorophyll degradation occurred simultaneously through multiple enzymatic paths and was not restricted only to the chlorophyllase enzyme. The author, working with three temperatures, verified that high temperatures, over $40^{\circ} \mathrm{C}$, and the fast rate of moisture loss by the seed, caused denaturation of all the enzymes, including chlorophyllase, which is the most heat resistant.

Since chlorophyllase and chlorophyll are found in the chloroplast thylakoids, the mechanism by which the contact between enzyme and substrate is controlled remains unknown. In vitro, its activity requires high temperatures and moist media and in vivo, it has latent activity in the 
chloroplasts under natural conditions (Schoch and Brown, 1987; Johnson-Flanagan and Thiagarajah, 1990; Takamyia et al., 2000).

There are few reports in the literature on the physiological degradation mechanism of chlorophyll in soybean seed, as a post-harvest biochemical process or senescence (Costa et al., 2001; Sinnecker, 2002; FrançaNeto et al., 2005). These studies focused on the main factors that might result in green seed production, the influence of this occurrence on the physiological quality of seed lots and chlorophyll degradation during maturation and drying. However, different performances regarding the chlorophyll contents can be obtained, depending on the cultivar, and this retention is affected equally by the genotype and adverse climatic conditions.

\section{CONCLUSIONS}

Soybean genotypes respond differently to the expression of green seed production under temperature and water stresses. The cultivars MG/BR 46 (Conquista) and BRS 251 (Robusta) were considered more susceptible to green seed production compared to 'BRS 133' and 'CD 206'.

The intensity of the production of the green seed characteristic is affected by genotypic response and unfavorable environmental conditions

Soybean plants submitted to water and temperature stresses at $\mathrm{R}_{6}$ produce high levels of green seed, which are small, light and have high chlorophyll contents and low chlorophyllase activity.

The contents of the $a, b$ and total chlorophylls in GS are inversely proportional to the chlorophyllase activity.

\section{ACKNOWLEDGMENTS}

The authors thank Dr. Veronica Yumi Kataoka from the Federal University of Lavras for her collaboration in the statistical analyses.

\section{REFERÊNCES}

ARNON, D.I. Copper enzymes in isolated chloroplasts: polyphenoloxydase in Beta vulgaris. Plant Physiology, v.24, n.1, p.1-15, 1949.

BLACKMAN, S.A.; OBENDORF, R.L.; LEOPOLD, A.C. Maturation proteins and sugars in desiccation tolerance of developing soybean seeds. Plant Physiology, v.100, n.1, p.225-230, 1992.
BOHNER, H. Green soybeans. 2002. Disponível em: < http://www.omafra.gov.on.ca/english/crops/field/news/ croptalk/2002/ct_1102a2.htm>. Acesso em: 12 July, 2005.

COSTA, N.P.; FRANÇA-NETO, J.B.; PEREIRA, J.E.; MESQUITA, C.M.; KRZYZANOWSKI, F.C.; HENNING, A.A. Efeito de sementes verdes na qualidade fisiológica de sementes de soja. Revista Brasileira de Sementes, Brasília, Brasília, v. 23, n. 2, p. 102-107, 2001.

CROOKSTON, R.K.; HILL, D.S. A visual indicator of the physiological maturity of soybean seed. Crop Science, v.18, n.5, p.867-870, 1978.

DORNBOS, D.L.; MCDONALD, M.B. Mass and composition of developing soybean seeds at five reproductive growth stages. Crop Science, Madison, v.25, n.3, p.624-630, 1986.

EGLI, D.B. Seed biology and the yield of grain crops. New York, CABI International, 1998. 178p.

EMPRESA BRASILEIRA DE PESQUISA AGROPECUÁRIA. Centro Nacional de Pesquisa de Solos. Manual de métodos de análise de solo. 2. ed. Rio de Janeiro: EMBRAPA-CNPS, 1997. 212 p.

FERREIRA, D.F. Análises estatísticas por meio do Sisvar para Windows versão 4.0 In: REUNIÃO ANUAL DA REGIÃO BRASILEIRA DA SOCIEDADE INTERNACIONAL DE BIOMETRIA, 45., São Carlos, 2000. Programas e resumos... São Carlos, SP: UFSCar, 2000. p. 255-258.

FRANÇA-NETO, J.B.; KRZYZANOWSKI, F.C. Sementes enrugadas: novo problema na soja. Londrina: EMBRAPACNPSo, 1990. 4p. (EMBRAPA-CNPSo. Comunicado Técnico, 46).

FRANÇA-NETO, J.B.; PÁDUA, G.P.; CARVALHO, M.L. M. de, COSTA, O.; BRUMATTI, P.S.R.; KRZYZANOWSKI, F.C.; COSTA, N.P. da, HENNING, A.A.; SANCHES, D.P. Semente esverdeada de soja e sua qualidade fisiológica. Londrina: Embrapa Soja, 2005. 8 p. (Embrapa Soja. Circular Técnica, 38).

HEATON, J.W.; MARANGONI, A.G. Chlorophyll degradation in processed foods and senescent plant tissues. Trends in Food Science and Technology, Oxford, v.7, n.1, p.8-15, 1996.

JOHNSON-FLANAGAN, A.M.; THIAGARAJAH, M.R. Degreening in canola (Brassica napus, cv. Westar) embryos under optimum conditions. Journal of Plant Physiology, v.136, n.2, p.180-186, 1990.

MANGOS, T.J.; BERGER, R.G. Determination of major 
chlorophyll degradation products. Lebensmittel Unters Forsch A, v.204, n.5, p.345-350, 1997.

MARCOS FILHO, J. Fisiologia de sementes de plantas cultivadas. Piracicaba: FEALQ, 2005. 495 p.

McGREGOR, D.I. Influence of environment and genotype on rapeseed/canola seed chlorophyll content. Seed Science and Technology, v.19, n.1, p.107-116, 1991.

R. Development Core Team. R: A language and environment for statistical computing. $R$ Foundation for Statistical Computing, Vienna, Áustria. 2005, ISBN 3-900051-07-0. Disponível em: <http://www.R-project. org>. Acesso em: 25 set. 2009.

RITCHIE, S.W.; HANWAY, J.J.; THOMPSON, C.E.; BENSON, G.O. How a soybean plant develops. Ames: Iowa State University of Science and Technology: Cooperative extension, service, 1994. 20p. (Special Report, $53)$.

SABATER, B.; RODRIGUEZ M.T. Control of chlorophyll degradation in detached leaves of barley and oat through effect of kinetin on chlorophyllase levels. Plant Physiolology, v.43 p.274-276, 1978.

$\mathrm{SCHOCH}, \mathrm{S}$. BROWN, J. The action of chlorophyllase on chlorophyll-protein complexes. Journal of Plant Physiology, v.126, p.483-494, 1987.

SINNECKER, P. Degradação da clorofila durante a maturação e secagem de sementes de soja. 2002. $103 \mathrm{f}$. Tese (Doutorado em Ciência dos Alimentos) - Faculdade de Ciências Farmacêuticas - Universidade de São Paulo,
São Paulo, 2002.

STANGARLIN, J. R. Atividades de ribulose-1,5-bifosfato carboxilase (Rubisco), clorofilase, B-1,3 glucanase e quitanase e conteúdo de clorofila em cultivares de feijoeiro (Phaseolus vulgaris) infectados com Uromyces appendiculaatus Ou Phaeoisariopsis griseola. 1999. 119p. Tese (Doutorado em Fitotecnia) c- Escola Superior de Agricultura Luiz de Queiroz, Piracicaba.

STANGARLIN, J. R.; PASCHOLATI, S. F.; LABATE, C. A. Efeito de Phaeoisariopsis griseola na atividade de ribulose-1,5-bifosfato carboxilase-oxigenase, clorofilase, $\beta-1,3$ glucanase e quitinase em cultivares de Phaseolus vulgaris. Fitopatologia Brasileira, v. 25, n. 1, p. 59-66, 2000.

TAKAMYIA, K.; TSUCHIYA, T.; OHTA, H. Degradation pathway(s) of chlorophyll: what has gene cloning revealed? Trends Plant Science, London, v.5, n.10, p.426-431, 2000.

THEANJUMPOL, P. Effect of moisture content and curing temperature on seed color and quality of soybean. 2002. Thesis (M Sc.), Chiang Mai University.

TEKRONY, D.M.; EGLI, D.B.; PHILLIPS, A.D. Effect of field weathering on the viability and vigor of soybean seed. Agronomy Journal, v.72, n.5, 749-753, 1980.

TEWARI, A.K.; TRIPATHY, B.C. Temperature-stressinduced impairment of chlorophyll biosynthetic reactions in cucumber and wheat. Plant Physiology, v.117, p.851-858, 1998. 